\title{
NOXIOUS EFFECTS OF FORMALIN TREATED CADAVERS ON MEDICAL STUDENTS DURING DISSECTION
}

\author{
Rashmi Jain 1 , Ankit Jain², Sandeep Marskole 3
}

${ }^{1}$ Lab Head, Consultant Pathologist, SRL Diagnostics Ltd., Malviya Nagar, Bhopal (M.P.), India

${ }^{2}$ Ex-Resident, Department of Anatomy, Gandhi Medical College, Bhopal, Madhya Pradesh.

${ }^{3}$ Assistant Professor, Department of Anatomy, Gandhi Medical College, Bhopal, Madhya Pradesh.

\section{ABSTRACT}

\section{BACKGROUND}

A cadaver is preserved via the infusion of formalin, which contains formaldehyde. Formaldehyde is colourless and flammable gas, which has an irritating and pungent smell. Formalin after evaporation from the embalmed bodies turns into fumes and is responsible for health hazard for all medical students and faculties.

The aim of this study was to find out and quantify the noxious effects of formalin.

\section{MATERIALS AND METHODS}

The present study was conducted on 140 medical students, who were unconsciously routinely exposed to formaldehyde fumes for two hours daily ( 6 days in a week) during dissection. They were asked to fill up the questionnaires, which were related to symptoms arising due to inhalation of formaldehyde fumes within the dissection hall.

\section{RESULTS}

In our study, $79.28 \%$ students have reported excessive lacrimation and also felt that it was the most irritating and troublesome symptom (57.14\%). The unpleasant smell was felt by $76.42 \%$ students and $63.57 \%$ students experienced that it was the first symptom to develop. Other symptoms reported were running nose (62.14\%), itching sensation in eyes (68.57\%), cough (18.57\%), sore throat (20.71\%), difficulty in breathing (24.28\%) and headache (51.42\%).

\section{CONCLUSION}

Medical students are exposed to formaldehyde during their dissection course and exposure to formaldehyde fumes is hazardous to the health of medical students. The harmful effects of formalin can be reduced by some preventive measures like good exhaust ventilation in dissection hall and by wearing protective devices like gloves, masks and aprons, etc.

\section{KEYWORDS}

Formalin, Formaldehyde, Toxicity, Medical Students, Cadaver Preservatives.

HOW TO CITE THIS ARTICLE: Jain R, Jain A, Marskole S. Noxious effects of formalin treated cadavers on medical students during dissection. J. Evolution Med. Dent. Sci. 2017;6(63):4584-4587, DOI: 10.14260/Jemds/2017/992

\section{BACKGROUND}

Formalin is a colourless irritative liquid, which contains $37 \%$

- $50 \%$ of aqueous solution of dissolved formaldehyde. Noxious effect of formalin is principally because of the formaldehyde which is colourless, combustible gas and intensely soluble in water.[1] Formalin is broadly utilised as a part of paint, textile, cosmetic, wood and plastic industries. It has likewise been extensively utilised as germicide, fungicide, disinfectant and preservative in Anatomical and Pathological gross specimens in Medical Institutes and Hospitals.[2]

In Medical Colleges, dead bodies are preserved for routine dissection. Treating of the dead body is accomplished by infusion of chemical fluid in the body which contains formalin, glycerin, alcohol, carbolic acid and dye.[3] Embalming fluid is generally infused via femoral arteries or internal carotid arteries.

Financial or Other, Competing Interest: None.

Submission 30-06-2017, Peer Review 24-07-2017,

Acceptance 31-07-2017, Published 07-08-2017.

Corresponding Author:

Dr. Ankit Jain,

S/o. Subodh Kumar Jain,

Near Jain Mandir, Shakti Nagar (Neha Nagar),

Makronia, Dist. Sagar-470004, Madhya Pradesh.

E-mail: ankitjain6285@gmail.com

DOI: $10.14260 /$ jemds $/ 2017 / 992$
These fluids have precise roles in preservation, fixation, denaturation, solidification of tissue protein and maintenance of the integrity of the anatomic relation. [4] The dispersion of formaldehyde fumes from dead bodies during dissection can deliver high exposures among medical students and faculties. The level of exposure to formaldehyde depends on the time spent in dissection hall and furthermore the ventilation of the dissection hall. ${ }^{[5-7]}$

The concentration of formaldehyde in the air is universally expressed in terms of Parts Per Million [PPM].[8] The permissible exposure limit for formaldehyde in the working environment is $0.75 \mathrm{ppm}$ measured as an 8-hour Time-Weighted Average (TWA). A second admissible exposure limit in the form of a Short-Term Exposure Limit (STEL) of $2 \mathrm{ppm}$, which is the highest exposure approved during a 15-minute period.[9] Exposure of formalin above permissible limit may create physiological modifications of respiratory mucosa, which causes upper airway irritation, sore throat, tingling and burning sensations of the nose and nasal blockage. Antagonistic impacts of breathing in formaldehyde turn out to be more as the concentration level of formalin increases.[10] Various investigations recommend that noteworthy changes may happen in lung and cardiac function after prolonged exposure to formalin. $[7,11,12]$

The present study has been embraced to evaluate the dangerous impacts of formaldehyde vapour emerging from 
embalming fluids over Indian medical students during routine dissection.

\section{MATERIALS AND METHODS}

The present study was carried out in the Department of Anatomy, Gandhi Medical College, Bhopal (MP) over a period of two years (2014 - 2015). After the permission from the Institutional Ethics Committee, the cross-sectional study was conducted on 140 healthy medical students who were in the age group of 18 - 20 years with no history of previous exposure to formaldehyde fumes. The health status of the student was ascertained through history taking and medical examination. Students with present and/or past history of smoking; any history of cardiac, pulmonary, skin and other systemic diseases were excluded from the study. Written informed consent was taken from all the medical students who were included in this study.

The students were informed about the source of cadavers, a method of preservation of cadavers and preservative fluids. The students were unconsciously routinely exposed to formaldehyde fumes for two hours daily ( 6 days in a week), during dissection. They were asked to fill up the questionnaire, which included questions regarding symptoms arising due to inhalation of formaldehyde fumes within the dissection hall. These symptoms were graded on a scale of 0 2 as follows: Grade 0- Never experienced, Grade IExperienced occasionally, Grade II- Strongly experienced. The students were also asked to clarify that among the symptoms which was first to develop and which was the most irritating and intolerable.

\section{RESULTS}

In the present study following exposure to formaldehyde fumes, excessive lacrimation was seen in $79.28 \%$ students, whereas $68.57 \%$ and $17.14 \%$ students felt itching sensation in eyes and blurring of vision respectively. Among the dermal symptoms, itching sensation in hands and burning sensation in skin were felt by $29.28 \%$ and $9.28 \%$ students respectively, whereas rashes and eruptions within the skin were seen in $7.86 \%$ and $23.57 \%$ students respectively [Table 1].

Among the GIT symptoms, post dissection nausea and vomiting was felt by $30.71 \%$ students, whereas disturbance in appetite was felt by $25.71 \%$ students following exposure to formaldehyde fumes. Among the pulmonary symptoms, unpleasant smell and tingling sensation were felt by $76.42 \%$ and $31.43 \%$ students respectively, whereas running nose and cough was seen in $62.14 \%$ and $18.57 \%$ students respectively. A sore throat and difficulty in breathing were complained by $20.71 \%$ and $24.28 \%$ students respectively [Table 2].

In this study, we found that $51.42 \%$ students complained of headache following exposure to formaldehyde fumes. Fainting episodes and restlessness were felt by $15 \%$ and $19.28 \%$ students respectively, whereas $17.85 \%$ students complained disturbance of sleep and lack of concentration following exposure to formaldehyde fumes [Table 3].

In the present study, $63.57 \%$ students experienced unpleasant smell as the first symptom, whereas excessive lacrimation was experienced as the first symptom in $19.85 \%$ students. Only $7.86 \%$ and $9.28 \%$ students experienced itching sensation in eyes and running nose as the first symptom respectively. Among all the symptoms, excessive lacrimation was experienced as the most irritable symptoms in $57.14 \%$ students, whereas $27.14 \%$ students felt unpleasant smell as the most intolerable symptom. Only $2.14 \%$ and $7.86 \%$ students experienced itching sensation in eyes and running nose as the most irritating symptom respectively. Only one student felt a sore throat as the most intolerable symptom following exposure to formaldehyde fumes [Table $4]$.

\begin{tabular}{|c|c|c|c|}
\hline \multirow{2}{*}{ Symptoms } & \multicolumn{3}{|c|}{ Number of the Students Affected } \\
\hline & Grade 0 & Grade I & Grade II \\
\hline \multicolumn{4}{|c|}{ Ocular Symptoms } \\
\hline $\begin{array}{l}\text { Excessive } \\
\text { lacrimation }\end{array}$ & $29(20.71 \%)$ & $99(70.71 \%)$ & $12(8.57 \%)$ \\
\hline $\begin{array}{l}\text { Itching sensation } \\
\text { in eyes }\end{array}$ & $44(31.43 \%)$ & $87(62.14 \%)$ & $9(6.43 \%)$ \\
\hline Blurring of vision & $\begin{array}{c}116 \\
(82.86 \%) \\
\end{array}$ & $21(15 \%)$ & $3(2.14 \%)$ \\
\hline \multicolumn{4}{|c|}{ Dermal Symptoms } \\
\hline Itching in hands & $99(70.71 \%)$ & $36(25.71 \%)$ & $5(3.57 \%)$ \\
\hline Rashes & $\begin{array}{c}129 \\
(92.14 \%) \\
\end{array}$ & $11(7.86 \%)$ & 0 \\
\hline Burning sensation & $\begin{array}{c}127 \\
(90.71 \%)\end{array}$ & $12(8.57 \%)$ & $1(0.71 \%)$ \\
\hline Skin eruptions & $\begin{array}{c}107 \\
(76.42 \%) \\
\end{array}$ & $30(21.43 \%)$ & $3(2.14 \%)$ \\
\hline \multicolumn{4}{|c|}{\begin{tabular}{|} 
Table 1. Ocular and Dermal Effects of Formalin on Medica \\
Students $(n=140)$
\end{tabular}} \\
\hline
\end{tabular}

\begin{tabular}{|c|c|c|c|}
\hline \multirow{2}{*}{ Symptoms } & \multicolumn{3}{|c|}{ Number of the Students Affected } \\
\hline & Grade 0 & Grade I & Grade II \\
\hline \multicolumn{4}{|c|}{ GIT Symptoms } \\
\hline $\begin{array}{l}\text { Post dissection } \\
\text { nausea and } \\
\text { vomiting }\end{array}$ & $97(69.28 \%)$ & $40(28.57 \%)$ & $3(2.14 \%)$ \\
\hline Disturbed appetite & $104(74.28 \%)$ & $25(17.85 \%)$ & $11(7.86 \%)$ \\
\hline \multicolumn{4}{|c|}{ Respiratory Tract Symptoms } \\
\hline Unpleasant smell & $33(23.57 \%)$ & $80(57.14 \%)$ & 27 (19.28\%) \\
\hline $\begin{array}{l}\text { Tingling sensation } \\
\text { in nose }\end{array}$ & $96(68.57 \%)$ & $37(26.43 \%)$ & $7(5 \%)$ \\
\hline Running nose & $53(37.85 \%)$ & $74(52.85 \%)$ & $13(9.28 \%)$ \\
\hline Cough & $114(81.42 \%)$ & $23(16.43 \%)$ & $3(2.14 \%)$ \\
\hline Sore throat & $111(79.28 \%)$ & $28(20 \%)$ & $1(0.71 \%)$ \\
\hline $\begin{array}{c}\text { Difficulty in } \\
\text { breathing }\end{array}$ & $106(75.71 \%)$ & $29(20.71 \%)$ & $5(3.57 \%)$ \\
\hline \multicolumn{4}{|c|}{$\begin{array}{c}\text { Table 2. Effects of Formalin on GIT and Respiratory Tract } \\
\text { in Medical Students }(n=140)\end{array}$} \\
\hline
\end{tabular}

\begin{tabular}{|c|c|c|c|}
\hline \multirow{2}{*}{ Symptoms } & \multicolumn{3}{|c|}{ Number of the Students Affected } \\
\cline { 2 - 4 } & Grade 0 & Grade I & Grade II \\
\hline Headache & $68(48.57 \%)$ & $58(41.43 \%)$ & $14(10 \%)$ \\
\hline $\begin{array}{c}\text { Lack of } \\
\text { concentration }\end{array}$ & $115(82.14 \%)$ & $23(16.43 \%)$ & $2(1.43 \%)$ \\
\hline Restlessness & $113(80.71 \%)$ & $26(18.57 \%)$ & $1(0.71 \%)$ \\
\hline $\begin{array}{c}\text { Disturbance of } \\
\text { sleep }\end{array}$ & $115(82.14 \%)$ & $21(15 \%)$ & $4(2.86 \%)$ \\
\hline $\begin{array}{c}\text { Fainting } \\
\text { episodes }\end{array}$ & $119(85 \%)$ & $17(12.14 \%)$ & $4(2.86 \%)$ \\
\hline
\end{tabular}

Table 3. Neurobehavioural Effects of Formalin on Medical Students $(n=140)$ 


\begin{tabular}{|c|c|c|}
\hline Symptoms & $\begin{array}{c}\text { Symptom } \\
\text { Appearing First }\end{array}$ & $\begin{array}{l}\text { Most Irritable } \\
\text { Symptoms }\end{array}$ \\
\hline Unpleasant smell & $89(63.57 \%)$ & $38(27.14 \%)$ \\
\hline Running nose & $13(9.28 \%)$ & $11(7.86 \%)$ \\
\hline $\begin{array}{c}\text { Itching sensation in } \\
\text { eyes }\end{array}$ & $11(7.86 \%)$ & $3(2.14 \%)$ \\
\hline Excessive lacrimation & $27(19.85 \%)$ & $80(57.14 \%)$ \\
\hline Headache & 0 & $7(5 \%)$ \\
\hline Sore throat & 0 & $1(0.71 \%)$ \\
\hline Total & $140(100 \%)$ & $140(100 \%)$ \\
\hline
\end{tabular}

\section{DISCUSSION}

It is noted that formaldehyde can cause sick house syndrome (sick building syndrome), which is represented by a headache, nausea, mucosal irritation and chest symptoms.[13] Breathing is the most prevalent way of exposure to formaldehyde. Other courses of human introduction to formaldehyde are by eye and dermal contact. Along these lines skin, eyes and upper respiratory tract are most influenced parts of the body after formaldehyde presentation. Since formaldehyde is water solvent, it gets broken up in the mucosa and causes inflammatory, hyperplastic and degenerative changes in the mucosa of the objective organ. The broke down formaldehyde is converted into formate by the erythrocytic enzymes. Formate causes cross-linking of nucleic acids and amino acids that outcome in cell demise. At long last, formate is oxidised to carbon dioxide and is discharged through exhalation.[14]

Jain SR et al found that $74.8 \%$ understudies experienced excessive lacrimation as the first occurring symptom.[14] In contrast to above, we observed that $63.57 \%$ understudies experienced unpleasant smell as the first occurring symptom, whereas $57.14 \%$ understudies experienced excessive lacrimation as the most irritating and troublesome symptom [Table 4], which is similar to the findings reported by Kundu $S$ et al.[15]

Various studies showed that intense presentation of formalin was altering the cardiac and pulmonary functions. ${ }^{[7]}$ In the present study, tingling sensation in the nose and unpleasant smell were felt after exposure to formaldehyde fumes, which prompt a headache, rhinitis and dyspnoea [Table 2]. Wei CN et al observed that manifestations because of formalin presentation were subject to time spent in dissection hall and proposed that lessening time spent while dissection could reduce symptoms. ${ }^{[16]}$ Finding an alternative for formalin is likewise a decent choice to avert unsafe impacts of formaldehyde. Glutaraldehyde would be a reasonable option with similar fixation qualities. It is likewise trusted that ethanol glycerine fixation with thymol conservation can be a potential option to formaldehyde and phenol embalming.[17]

\section{CONCLUSION}

Formaldehyde can cause deleterious effects on the health of medical students and medical professionals during dissection. In this way, legitimate security measures should be taken by medical experts to counteract formalin poisonous quality. Some basic strategies, for example (a) Expanding wind current in the dissection hall by opening windows and doors, or by utilising unique nearby fumes ventilators in dissection halls, (b) By limiting direct skin contact with formalin by utilising defensive equipment, for example elastic gloves, masks and aprons, (c) Uncovering only the part of the dead body that is being dissected and periodic removal of fluid dripping collected in the body trays will help in diminishing the dangerous impacts of formalin.

\section{REFERENCES}

[1] Nisa G, Shah BA, Shahdad S, et al. Acute toxic effects of formalin on first year mbbs students during dissection in Gross anatomy laboratory. IOSR Journal of Dental and Medical Sciences 2016;15(8):56-9.

[2] Onyije FM, Avwioro OG. Excruciating effect of formaldehyde exposure to students in gross anatomy dissection laboratory. International Journal of Occupational and Environmental Medicine 2012;3(2):92-5.

[3] Patil GV, Shishirkumar, Thejeshwari, et al. Physical reactions of formalin used as cadaver preservative on first year medical students. Journal of Evidence Based Medicine and Healthcare 2014;1(5):279-83.

[4] Coleman R, Kogan I. An improved low-formaldehyde embalming fluid to preserve cadavers for anatomy teaching. Journal of Anatomy 1998;192(3):443-6.

[5] Bharadwaja A, Bafna G. Harmful effects of formalin on first MBBS students: a questionnaire study. J Evolution Med Dent Sci 2016;5(56):3823-5.

[6] Keil CB, Akbar-Khanzadeh F, Konecny KA. Characterizing formaldehyde emission rates in a gross anatomy laboratory. Applied Occupational and Environmental Hygiene 2001;16(10):967-72.

[7] Neginhal R, Herur A, Chinagudi S, et al. Cardiorespiratory effects of acute exposure to formaldehyde in gross anatomy laboratory in medical students - a comparative study. Medica Innovatica 2013;2(1):32-5.

[8] Raja DS, Sultana B. Potential health hazards for students exposed to formaldehyde in the gross anatomy laboratory. Journal of Environmental Health 2012;74(6):36-40.

[9] Formaldehyde. Occupational Safety and Health Administration (OSHA). 2011. https://www.osha.gov/OshDoc/data_General_Facts/f ormaldehyde-factsheet.pdf.

[10] Khaliq F, Tripathi P. Acute effects of formalin on pulmonary functions in gross anatomy laboratory. Indian Journal of Physiology and Pharmacology 2009;53(1):93-6.

[11] Mathur N, Rastogi SK. Respiratory effects due to occupational exposure to formaldehyde: systematic review with meta-analysis. Indian Journal of Occupational and Environmental Medicine 2007;11(1):26-31.

[12] Takeshita D, Nakajima-Takenaka C, Shimizu J, et al. Effects of formaldehyde on cardiovascular system in, In Situ Rat Hearts. Basic Clinical Pharmacology Toxicology 2009;105(4):271-80.

[13] Hodgson M. Sick building syndrome. Occupational medicine. Philadelphia, Pa: 2000;15(3):571-85. 
[14] Jain SR, Nahar PS, Baig MM. Study of formalin toxicity in I MBBS students. International Journal of Science and Research 2012;1(3):233-5.

[15] Kundu S, Gangrade P. Study of the toxic effects of formaldehyde vapours within the dissection hall on the first year Indian medical students. Int J Anat Res 2015; 3(2):1179-90.
[16] Wei CN, Harada K, Ohmori S, et al. Subjective symptoms of medical students exposed to formaldehyde during a gross anatomy course. Int J Immunopathol Pharmacol 2007;20(2 Suppl 2):23-5.

[17] Hammer N, Loffler S, Feja C, et al. Ethanol-glycerine fixation with thymol conservation: a potential alternative to formalaldehyde exposure. Anat Sci Edu 2012;5(4):225-33. 